DOI 10.4467/2543733XSSB.21.023.13816

PIOTR OBACZ

Uniwersytet Jagielloński

\title{
Recenzja książki: \\ T. Slomka (red.), Demokracja konstytucyjna w Polsce, Dom Wydawniczy ELIPSA, Warszawa 2019, ss. 301
}

Wieloautorska monografia pod redakcją dr. hab. Tomasza Słomki to opracowanie ważne, użyteczne i pouczające. Poziom merytoryczny książki koresponduje z jej rangą. Jest to bowiem publikacja poświęcona pamięci Profesora Tadeusza Mołdawy, zmarłego w czerwcu 2019 roku wybitnego politologa i prawnika, dziekana Wydziału Dziennikarstwa i Nauk Politycznych Uniwersytetu Warszawskiego, wieloletniego pracownika Instytutu Nauk Politycznych UW, członka Trybunału Stanu. Profesor Tadeusz Mołdawa skupiał się w swych naukowych dociekaniach na zagadnieniach konstytucjonalizmu, uwarunkowań ustrojowych Polski i innych państw europejskich, transformacji polityczno-ustrojowych w Europie, parlamentaryzmu, systemu politycznego III RP, historii instytucji politycznych. Jego uczniowie i współpracownicy przygotowali monografię, która stanowi wyraz szacunku dla dorobku Profesora i która jest przykładem rzetelnych, a także nowatorskich analiz aktualnych procesów zachodzących w Polsce.

Twórcy monografii podjęli się omówienia niezwykle ważnego i aktualnego zagadnienia - kondycji demokracji konstytucyjnej w Polsce. Jest to temat w istocie autoteliczny, niemniej jego znaczenie obecnie wzrosło - ponownie, po bez mała dwudziestu pięciu latach, a to ze względu na bezprecedensowe działania rządzących, którzy po sukcesie wyborczym w 2015 roku konsekwentnie i systematycznie podważają porządek konstytucyjny i ustrojowy. Jak pisze Redaktor monografii: „Obowiązkiem naukowców jest zatem zdiagnozowanie istoty zmian we współczesnej demokracji konstytucyjnej oraz próba odpowiedzi na pytanie, czy rodzi się nowy model - demokracji nieliberalnej czy też totalitarnej (s. 11). Można stwierdzić, że zespół pod kierunkiem dr. hab. Tomasza Słomki wybrał dobry moment na zaprezentowanie swych politologiczno-prawnych analiz, z których wnioski tworzą złożony, ale jednoznaczny obraz ujawniający daleko idące zaburzenie mechanizmów konstytucyjnych w Polsce.

Należy zwrócić uwagę, iż omówienia zagadnień związanych z demokracją konstytucyjną w Polsce Autorzy dokonali w sposób dla czytelnika inspirujący, a to m.in. ze względu na przemyślany układ treści i dynamiczną narrację, a także dochowanie należytej 
staranności warsztatowej i zbieżności z kryteriami naukowości nauki o polityce i nauk prawnych. Omawiana praca odzwierciedla zróżnicowane instrumentarium naukowe ww. dyscyplin, które pozwoliło Autorom na zaprezentowanie i omówienie szerokiego, ale zarazem spójnego zestawu problemów. Nie jest to zbiór, który wyczerpuje wszystkie możliwe kwestie związane ze stanem demokracji konstytucyjnej, niemniej, powtarzając w ślad za Redaktorem monografii, ,wydaje się, że został osiagnięty pewien nadrzędny cel - a mianowicie ukazanie, że ustawa zasadnicza i cały towarzyszący jej ład to przestrzeń złożona i dynamiczna" (s. 10); zasygnalizowane przez Autorów zagadnienia, problemy i dylematy konstytucyjne i polityczne wyznaczają możliwe kierunki dalszych pogłębionych badań politologiczno-prawnych. Warto w tym miejscu podkreślić, że książka pod redakcją T. Słomki jest ważną odpowiedzią na bieżące procesy.

Tytuł monografii jest zwięzły i konkretny, w pełni koresponduje z treścią opracowania. Wyraża on zamysł przedstawienia specyfiki, dynamiki i kierunków rozwoju porządku konstytucyjnego w Polsce. W książce omówiono relatywnie szerokie spektrum zagadnień, które pozwalają uchwycić i zrozumieć sens ładu konstytucyjnego i jego aktualnej kondycji. Strukturę monografii podzielono na cztery części: „Wokół fundamentalnych dylematów konstytucyjnych”, „Ustrój polityczny a polityka i aktywność społeczna”, „Konstytucyjne i praktyczne dylematy władztwa państwowego”, „Myśl ustrojowa polskich partii politycznych". Taki układ pracy nie budzi zastrzeżeń; więcej nawet - jest zdecydowanie zachęcający, patrząc z perspektywy czytelnika.

W części pierwszej Tomasz Słomka w swym artykule analizuje stan demokracji konstytucyjnej w Polsce na tle modelu transformacji systemowej (s. 15-39). Analiza polskiej ścieżki ku demokracji konstytucyjnej pozwoliła Autorowi określić, jakie problemy, zagrożenia, dylematy i wyzwania stwarzają zmiany polityczne zachodzące po 2015 roku. Autor trafnie zwraca przy tym uwagę, że instytucje demokratyczne przewidziane Konstytucją z 1997 roku „okazały się nie w pełni odporne na działania zmierzające do totalizacji demokracji. Wynika to zarówno $z$ wad niektórych elementów procesu transformacji systemowej, jak i deficytu obywatelskiej kultury politycznej”. Krystian Complak w swej analizie porównawczej zajmuje się problematyką wartości i zasad konstytucyjnych (s. 40-63), ukazując napięcia między wartościami i zasadami Unii Europejskiej a tymi funkcjonującymi w obrębie poszczególnych państw europejskich. Izabela Malinowska omawia zagadnienie źródeł prawa w unormowaniach konstytucyjnych i ustawodawczych III RP (s. 64-83). Henryk Binkowski podejmuje kwestię ewentualnych zmian polskiej Konstytucji, odnosząc się przy tym do obecnych uwarunkowań politycznych (s. 84-95). Jacek Wojnicki kontynuuje rozważania na temat zmian w ustawie zasadniczej, analizując i porównując węgierski oraz polski kontekst polityczny (s. 96-116).

W drugiej części monografii Patryk Kałowski dokonuje analizy porównawczej Konstytucji oraz dokumentów stanowiących projekty ustawy zasadniczej, pod kątem norm dotyczących polityki społecznej (s. 119-135). Natomiast Anna Szustek i Małgorzata Szustek-Janowska przedstawiają interpretację konstytucyjnych regulacji odnoszących się do samorządów specjalnych (s. 136-150).

Część trzecia opracowania zawiera artykuły poświęcone organizacji aparatu państwowego. I tak, Krystyna Leszczyńska bada elementy dyskursu wyborczego z lat 1997-2015 dotyczące pozycji i roli parlamentu (s. 153-179); Ryszard Balicki analizuje stan władzy sądowniczej w Polsce, ukazując rozbieżności pomiędzy modelem konstytucyjnym a prak- 
tyką polityczną po 2015 roku (s. 180-191); Jolanta Itrich-Drabek objaśnia z kolei pozycję ustrojową służby cywilnej w Polsce (s. 192-211).

W części czwartej znalazły się artykuły zawierające analizy dyskursu politycznego na tematy związane z ustrojem Rzeczypospolitej. Jerzy Kuciński prezentuje główne kierunki zmian ustrojowych proponowanych przez partie polityczne w XXI wieku (s. 215-250); Tomasz Koziełło odtwarza koncepcję ustrojową „IV Rzeczypospolitej” w myśli politycznej Ligi Polskich Rodzin (s. 251-277); natomiast Dominik Szczepański podejmuje zagadnienie komunikowania politycznego w okresie konstytucyjnej kampanii referendalnej w 1997 roku (s. 278-297).

Wybór źródeł i metodologii, w oparciu o które przygotowano poszczególne artykuły, nie budzi zastrzeżeń; są one uzasadnione polem przedmiotowym analiz oraz dążeniem Autorów do objaśnienia interesujących Ich zagadnień. Wykorzystano reprezentatywną literaturę politologiczną i prawniczą oraz akty prawne, a także materiały ideowo-programowe polskich partii politycznych i inne materiały, które pozwoliły na ukazanie dyskursu publicznego.

Ostateczny efekt prac badaczy pod kierunkiem Tomasza Słomki wyróżnia się spójnością i komplementarnością zaprezentowanych analiz. Opracowanie jest dobrze przygotowane pod względem teoretycznym i metodologicznym, a wybrane przez Autorów zagadnienia należycie i bardzo interesująco omówione. Autorzy ustrzegli się spekulacji bądź formułowania nieuzasadnionych wniosków. Monografia Demokracja konstytucyjna w Polsce stanowi reprezentatywne omówienie przedmiotowego problematu oraz profesjonalny wkład w rozwój politologiczno-prawnej wiedzy naukowej, będąc zarazem godną formą uhonorowania Profesora Tadeusza Mołdawy. Niepodobna mieć wątpliwości, że jest to opracowanie o dużym walorze naukowym, mające wartość poznawczą, a także przejawiające walory dydaktyczne.

Piotr Obacz, dr, politolog, teoretyk polityki, członek Polskiego Towarzystwa Nauk Politycznych oraz International Political Science Association (Research Commitee 16: Socio-Politcal Pluralism, Research Commitee 33: The Study of Political Science as a Discipline); autor licznych opracowań naukowych i dydaktycznych oraz tekstów popularnonaukowych i komentarzy publicystycznych; w 2019 roku otrzymał główną nagrodę im. Prof. Jana Baszkiewicza w konkursie na najlepszą monografię politologiczną, a w 2018 roku został wyróżniony w konkursie im. Prof. Czesława Mojsiewicza na najlepszą rozprawę doktorską; zawodowo związany z Uniwersytetem Jagiellońskim i Akademią WSB w Dąbrowie Górniczej. 